\title{
Estimation of (co)variances for growth traits in Nellore cattle raised in the Humid Tropics of Brazil by random regression
}

\section{Estimação de componentes de (co)variâncias para características de crescimento em bovinos Nelore criados no Trópico Úmido do Brasil por meio de regressão aleatória}

\author{
Jorge Luís Ferreira ${ }^{1 *}$; Fernando Brito Lopes ${ }^{2}$; Leonardo de Sousa Pereira ${ }^{3}$; \\ Leandro Lopes Nepomuceno; ; José Américo Soares Garcia \\ Raysildo Barbosa Lôbo ; Roberto Daniel Sainz ${ }^{6}$
}

\begin{abstract}
Random regression models are currently used in genetic evaluation of beef cattle, because they allow changes in the mean and variance of the trait over time as well as estimation of (co) variances between any points along the growth curve. This study aimed to estimate (co)variances and genetic parameters for growth traits of Nelore cattle by random regression using models with heterogeneous and homogeneous residual variance. We utilized 23,278 weight records from birth to 550 days of age, from animals born between 1993 and 2010. The best-fitting model considered direct genetic, maternal genetic, permanent environmental animal and maternal permanent environmental effects, adjusted by fourth, third, sixth and fourth order polynomials, respectively. Heritability estimates for direct genetic effect increased from 120 to 450 days of age and then decreased at 550 days of age. Values at 120, 210, 365, 450 and 550 were $0.23,0.23,0.38,0.52$ and 0.43 , respectively. Estimates of maternal heritability were low for all ages analyzed, ranging from 0.01 to 0.08 . The genetic correlations were moderate to high, even at age extremes.
\end{abstract}

Key words: Heritability, performance, the growth curve

\section{Resumo}

Modelos de regressão aleatória são utilizados atualmente na avaliação genética de bovinos de corte, devido admitir mudanças na média e variâncias da característica ao longo do tempo, estimando (co) variâncias entre qualquer ponto na curva de crescimento do rebanho. Objetivou-se estimar componentes de (co)variâncias e parâmetros genéticos para características de crescimento de bovinos Nelore por meio de regressão aleatória, utilizando modelos com heterogeneidade e homogeneidade de variância residual. Utilizou-se de 23.278 registros de pesagens, do nascimento aos 550 dias de idade, nascidos entre 1993 e 2010. O modelo de melhor ajuste foi o que considerou os efeitos: genético direto, genético materno, de ambiente permanente do animal e o de ambiente permanente materno ajustado por polinômios de

1 Prof. Adjunto IV, Universidade Federal do Tocantins, Campus de Araguaína.,Araguaína, UFT, TO, Brasil. E-mail: jlferreira@uft. edu.br

2 Dr., Zooctecnista, Pós-doutorando University of Wisconsin, Madison, USA. E-mail: britolopes@wisc.edu

3 Médicos Veterinários Autônomos, Araguaína, TO, Brasil. E-mail: leonardospmedvet@hotmail.com; leandro_lopes795@ hotmail.com

4 Prof. Associado. Faculdade de Agronomia e Veterinária, Universidade de Brasília, Brasília, DF, Brasil. E-mail: jasgaria@unb.br

5 Diretor Presidente da Associação Nacional de Criadores e Pesquisadores, Ribeirão Preto, SP, Brasil. E-mail: raysildo@gmail.com

6 Prof. Associado, University of California, Davis, EUA. E-mail: rdsainz@ucdavis.edu

Author for correponence 
quarta, terceira, sexta e quarta ordens respectivamente. As estimativas de herdabilidade para o efeito genético direto se apresentaram crescentes dos 120 aos 450 dias de idade e tendo uma redução aos 550 dias de idade, observando-se valores de 0,$23 ; 0,23 ; 0,38 ; 0,52$ e 0,43 , respectivamente, sendo que, as estimativas de herdabilidades maternais foram baixas para todas as idades analisadas, variando de 0,01 a 0,08 . As correlações genéticas foram de moderada a alta magnitude, e mantendo-se moderada mesmo com o aumento da distância entre as idades.

Palavras-chave: Desempenho, herdabilidade, curva de crescimento

\section{Introduction}

Beef cattle production is an important component of Brazilian agribusiness. Beef production is expected to increase by $4.4 \%$ annually, supported by Brazil's great production potential, its first place ranking in world exports, second place in bovine production, and third place in consumption of animal products (BRASIL, 2011). However, productive and reproductive indices remain far below the ideal, mainly due to genetic factors, low reproductive efficiency, health aspects and soil and climatic factors (SANTOS et al., 2011).

The Brazilian cattle herd is comprised mainly of Zebu animals, $80 \%$ of which have a Nelore background. Growth performance varies according to region, due to diversity of climate and management systems (FERRAZ; ELER, 2010). Many studies conducted in different regions have analyzed the genetic and non-genetic factors that influence growth such as weights at different ages, growth curves and reproductive traits, confirming these differences (NEPOMUCENO et al., 2012; SANTOS et al., 2012; LIRA et al., 2013). However, few studies have utilized longitudinal data along with random regression methodology for Nelore cattle in the humid tropical region of Brazil.

Random regression models provide an alternative to conventional analyses (ALBUQUERQUE; MEYER, 2005; ALBUQUERQUE; EL FARO, 2008; BIASSUS et al., 2011), as they allow inclusion of all information from each animal, changes in the mean and variance of a trait over time, as well as estimation of (co) variances between any points along the growth curve through the (co)variance functions. Therefore, this study aimed to estimate (co)variances and genetic parameters for growth traits of Nelore cattle by random regression using models with heterogeneous and homogeneous residual variance.

\section{Material and Methods}

Genealogical and weight records from male and female Nelore cattle raised in Mato Grosso, Pará, Rondônia and Tocantins states, within the humid tropical region of Brazil, were provided by the National Association of Breeders and Researchers (Associação Nacional de Criadores e Pesquisadores - ANCP). A total of 23,278 weight records, from birth to 550 days of age, from animals born between 1993 and 2010, were analyzed. Only animals with birth weights between 20 and $45 \mathrm{~kg}$, and with at least four weight records, were included in these analyses.

Contemporary groups (CG) were defined by concatenation of environmental sources of variation, such as: season of birth, year of birth, management group, sex, and herd, such that weighing dates were common for each CG. For consistency, each CG had at least four animals, and sires with at least three progeny. The final data file contained 3,116 animals from 47 sires and 636 dams, distributed in 267 CG. The relationship matrix included 8,385 animals from all available generations. After data editing, each dam had an average of four progeny. Table 1 summarizes the overall structure of the data.

The model considered CG as a fixed effect, age of cow at calving (with linear and quadratic effects) as a covariate, and as random effects the direct additive and maternal genetic effects and permanent 
environmental animal and maternal effects. The residual was modeled considering seven age classes: 1 to 56,57 to 147,148 to 218,219 to 259 ,
260 to 301,302 to 372 , and 373 to 550 days of age, respectively. Legendre orthogonal polynomials were used to fit the mean population weight to age growth curve. The complete model was:

$$
y_{i j}=E F+\sum_{m=0}^{k_{b}-1} b_{m} \phi_{m}\left(t_{i}\right)+\sum_{m=0}^{k_{A}-1} \alpha_{j m} \phi_{m}\left(t_{i j}\right)+\sum_{m=0}^{k_{M}-1} \gamma_{j m} \phi\left(t_{i j}\right)+\sum_{m=0}^{K_{C}-1} \delta_{j m} \phi_{m}\left(t_{i j}\right)+\sum_{m=0}^{K_{Q}-1} \rho_{j m} \phi\left(t_{i j}\right)+e_{i j}
$$

where, $y_{i j}=i$-th measure of the $j$-th animal; $E F=$ combination of fixed effects; $b_{m}=$ fixed regression coefficient for the mean population growth curve; $\phi_{m}\left(t_{i}\right)=$ Legendre polynomial for the mean population growth curve according to age; $\phi_{m}\left(t_{i j}\right)=$ Legendre polynomial for the $j$-th animal's growth curve according to age $\left(t_{i}\right)$, with random additive direct and maternal genetic effects, and permanent animal and maternal environmental effects; $\alpha_{j m}, Y_{j m}$, $\delta_{j m}, \rho_{j m}=$ random regression coefficients for additive direct and maternal, and permanent animal and maternal environmental effects, respectively, for each animal; $k_{b}, k_{A}, k_{M}, k_{C}$ e $k_{Q}=$ order of Legendre polynomials for effects included in the model; $e_{i j}=$ random error associated with the $i$-th age of the $j$-th animal. We assumed $\mathrm{N} \sim\left(0, \sigma^{2}\right)$, i.e., normal distribution and unit variance.

Table 1. Data file structure.

\begin{tabular}{lr}
\hline Characteristics & Number \\
\hline Number of sires & 47 \\
Number of sires with progeny included in data set & 47 \\
Number of dams & 636 \\
Number of dams with progeny included in data set & 636 \\
Number of animals with records & 2,362 \\
Number of animals in relationship matrix & 5,330 \\
Number of animals with 3 records & 3,116 \\
Number of animals with 4 records & 680 \\
Number of animals with 5 records & 1,405 \\
Number of animals with 6 records & 730 \\
Number of animals with 7 to 10 records & 299 \\
Number of Contemporary Groups & 267 \\
\hline
\end{tabular}

(Co)variance components were estimated by restricted maximum likelihood, utilizing the WOMBAT software (MEYER; WOMBAT, 2007). Legendre orthogonal polynomials were used to model direct and maternal, and permanent animal and maternal environmental effects, so that 16 models were evaluated, with the order varying from 1 to 6 .

The different models were compared using Akaike's Information Criterion - AIC (AKAIKE,
1974) and Schwartz's Bayesian Information Criterion - BIC (SCHWARZ, 1998):

$$
\begin{gathered}
A I C=-2 \log L+2 p ; \\
B I C=-2 \log L+k x p \text {, sendo } k=\log (n) .
\end{gathered}
$$

where $\log L$ is the natural logarithm of the maximum likelihood function, $p$ is the number of parameters in the model, $k$ is a constant, and $n$ is the number of observations. These criteria allow comparison of unadjusted models and penalize over-parameterized models, the BIC being especially rigorous in these 
cases (WOLFINGER, 1993; NUNEZ-ANTÓN; ZIMMERMAN, 2000). The best-fit models were considered to be those that presented lowest values of AIC and BIC.

The following variance components were estimated: additive direct genetic variance $\sigma_{a}^{2}$, additive maternal genetic variance $\sigma_{m}^{2}$, genetic covariance between direct and maternal effects $\sigma_{a m}$, permanent environmental variance $\sigma_{e p}^{2}$, and residual variance $\sigma_{e}^{2}$. These components allowed estimation of the following parameters: direct heritability $\left(h_{a}^{2}=\sigma_{a}^{2} / \sigma_{p}^{2}\right)$, maternal heritability $\left(h_{m}^{2}=\sigma_{m}^{2} / \sigma_{p}^{2}\right)$, genetic correlation between direct and maternal effects $\left(r_{a m}\right)$; ratio of permanent environmental to phenotypic variance $(c)$; and total heritability $h_{T}^{2}=\left(\sigma_{a}^{2}+0.5 \sigma_{m}^{2}+1.5 \sigma_{a m}\right) / \sigma_{p}^{2}$.

\section{Results and Discussion}

Mean weights increased almost linearly with age (Figure 1). Likewise the standard deviations increased proportionally, i.e., variance also increased with age. The coefficients of variation increased up to 60 to 120 days of age and then decreased only slightly thereafter, confirming the strong association between the means and standard deviations. The observed trend justified the partition of residual variance into seven classes, because the greatest variation in standard deviations occurred from birth up to 365 days of age, after which the age intervals increased along with the variation in mean weight and standard deviation (Figure 1).

Figure 1. Number of observations and distribution of mean body weights by age in Nelore cattle, raised in the humid tropical region of Brazil.

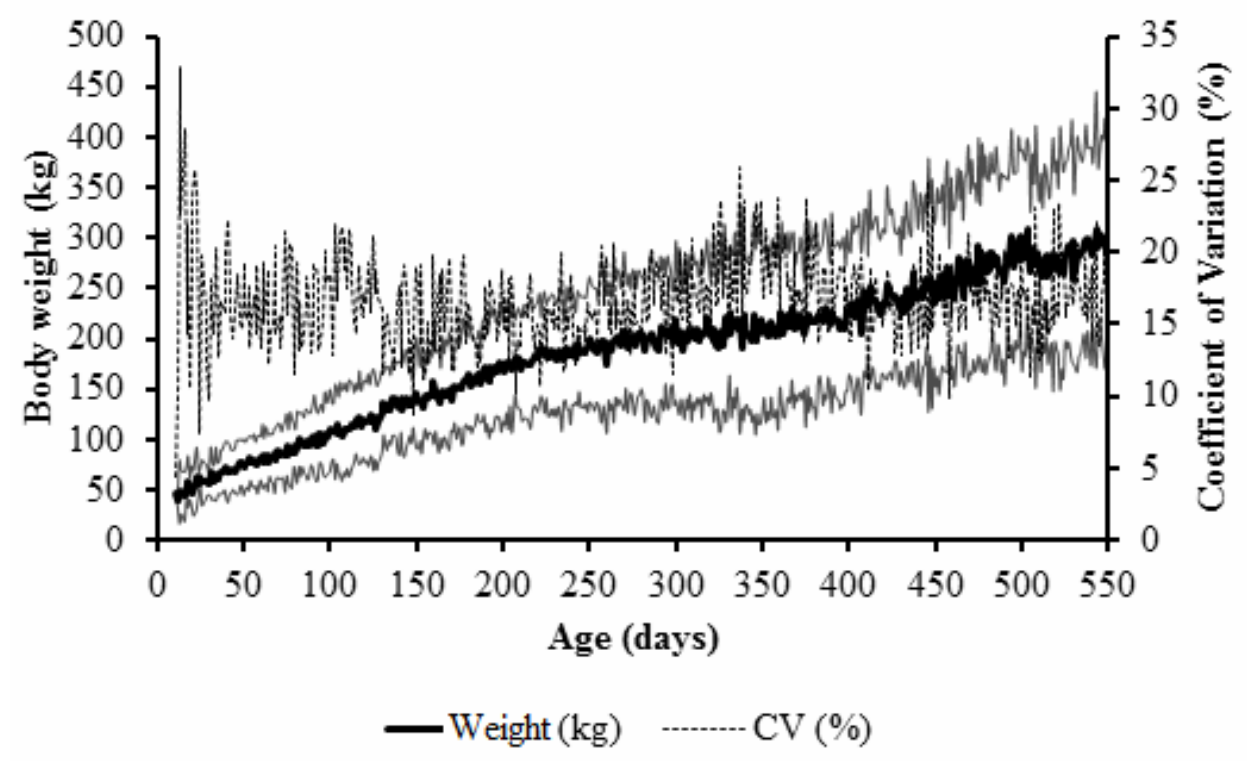

Rate of gain was relatively constant after 210 days of age (Figure 2), probably due to the prevailing pasture-based production system that imposes a nutritional (i.e. environmental) constraint on performance. However, genetic selection for weight in Brazil is generally done at ages above 12 months, which may impact reproductive performance of mature cows as well as the economic efficiency of the system, as cattle undergoing selection are maintained on pasture for longer periods. Therefore, selection at younger ages would be advantageous, because the correlations between weights at younger (120 and 210) and older (365, 450 and 550) days of age were high and positive. 
Figure 2. Distribution of average daily gains of Nelore cattle, raised in the humid tropical region of Brazil.

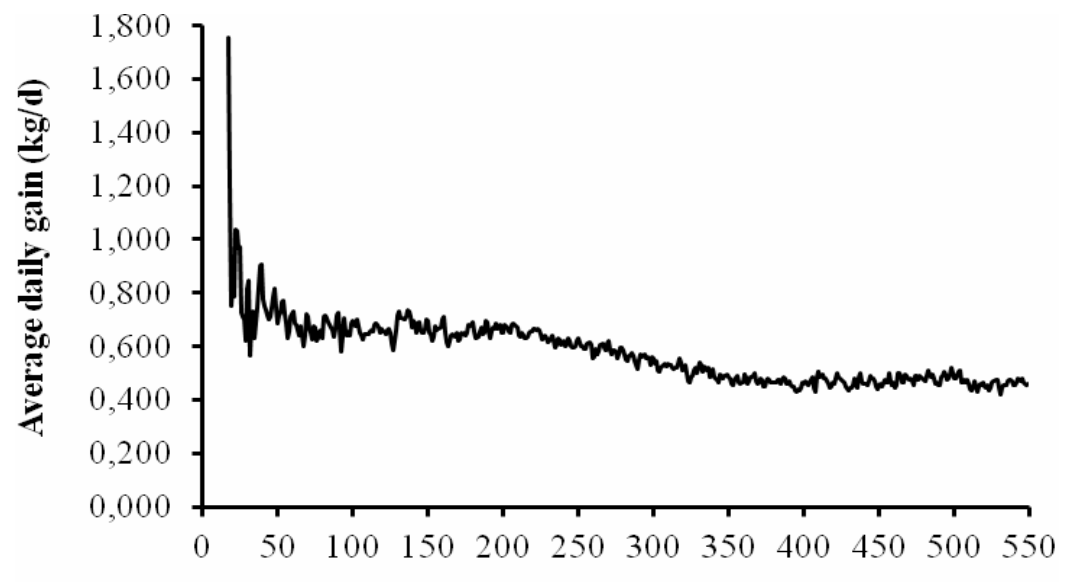

Age (days)

Therefore, we suggest that selection for weight be intensified at younger ages (120 or 210 days), as during this period the animal undergoes rapid growth and development, which could contribute to lowering the age at slaughter. By contrast, selection for increased weight at later ages (365, 450 or 550 days) may lead to selection of latermaturing animals, which would increase the costs of production. Clearly, genetic selection must consider other criteria besides weight (the most common selection criterion) in order to maximize the profit function.

According to the AIC e BIC, model M4465 with 57 parameters presented the best fit with homogeneous residual variance (Table 2). When residual variance was heterogeneous, the AIC and BIC indicated model M4364 with 54 parameters as the best fit (Table 3). Estimates of Log L presented in Tables 2 and 3 were significant $(\mathrm{P}<$ 0.05 ) according to the maximum likelihood test, confirming that the model including seven variance classes with heterogeneous residual variance was the best overall. The AIC and BIC criteria impose penalties according to the number of parameters being estimated. Therefore, the model with the fewest parameters, utilizing variance classes (model 4364) was the best fit overall for the data utilized in this study, bearing in mind that the distribution of animal numbers, standard deviations and especially coefficient of variation in the data varied with age.

Thus, modelingresidual variancealong the growth curve is necessary to obtain accurate parameter estimates, with no biases due to additive direct and maternal genetic effects, and permanent animal and maternal environmental effects, avoiding errors in genetic classification of animals. As pointed out by Dias et al. (2006), estimates of genetic parameters may be influenced by the regression model utilized. The partition of random effects, separating genetic and environmental effects into direct and maternal components is essential to correctly model these data. The model used for residual variance and the order of the fitted polynomials can also impact the estimates of variance components. 
Table 2. Order of polynomials for direct $\left(\mathrm{k}_{\mathrm{a}}\right)$ and maternal $\left(\mathrm{k}_{\mathrm{m}}\right)$ genetic effects, permanent animal $\left(\mathrm{k}_{\mathrm{p}}\right)$ and maternal $\left(\mathrm{k}_{\mathrm{c}}\right)$ environment, number of parameters (NP), $\log$-likelihood function $(\log (\mathrm{L}))$, Akaike (AIC) and Schwarz's Bayesian (BIC) information criteria for models with homogeneous residual variance.

\begin{tabular}{ccccccccc}
\hline Model & $\mathbf{k}_{\mathbf{a}}$ & $\mathbf{k}_{\mathbf{m}}$ & $\mathbf{k}_{\mathbf{p}}$ & $\mathbf{k}_{\mathbf{c}}$ & $\mathbf{N P}$ & $\mathbf{L o g}(\mathbf{L})$ & $\mathbf{A I C}$ & $\mathbf{B I C}$ \\
M3311 & 3 & 3 & 1 & 1 & 15 & $-57,744$ & 115,519 & 115,566 \\
M3322 & 3 & 3 & 2 & 2 & 19 & $-57,724$ & 115,487 & 115,546 \\
M3333 & 3 & 3 & 3 & 3 & 25 & $-57,691$ & 115,432 & 115,510 \\
M4353 & 4 & 3 & 5 & 3 & 38 & $-49,859$ & 99,795 & 99,912 \\
M4363 & 4 & 3 & 6 & 3 & 44 & $-47,305$ & 94,699 & 94,835 \\
M4364 & 4 & 3 & 6 & 4 & 48 & $-39,001$ & 78,099 & 78,247 \\
M4422 & 4 & 4 & 2 & 2 & 27 & $-57,649$ & 115,352 & 115,436 \\
M4433 & 4 & 4 & 3 & 3 & 33 & $-57,686$ & 115,439 & 115,541 \\
M4453 & 4 & 4 & 5 & 3 & 42 & $-43,425$ & 86,934 & 87,064 \\
M4454 & 4 & 4 & 5 & 4 & 46 & $-50,428$ & 100,948 & 101,090 \\
M4464 & 4 & 4 & 6 & 4 & 52 & $-47,848$ & 95,800 & 95,961 \\
M4465 & 4 & $\mathbf{4}$ & $\mathbf{6}$ & $\mathbf{5}$ & $\mathbf{5 7}$ & $\mathbf{- 3 8 . 8 7 6}$ & $\mathbf{7 5 . 6 1 0}$ & $\mathbf{7 5 . 7 8 6}$ \\
M4466 & 4 & 4 & 6 & 6 & 63 & $-40,324$ & 80,774 & 80,969 \\
M4533 & 4 & 5 & 3 & 3 & 38 & $-49,869$ & 99,815 & 99,933 \\
M4544 & 4 & 5 & 4 & 4 & 46 & $-42,023$ & 84,138 & 84,281 \\
M4555 & 4 & 5 & 5 & 5 & 56 & $-39,142$ & 78,396 & 78,569 \\
\hline
\end{tabular}

Table 3. Order of polynomials for direct $\left(\mathrm{k}_{\mathrm{a}}\right)$ and maternal $\left(\mathrm{k}_{\mathrm{m}}\right)$ genetic effects, permanent animal $\left(\mathrm{k}_{\mathrm{p}}\right)$ and maternal $\left(\mathrm{k}_{\mathrm{c}}\right)$ environment, number of parameters (NP), $\log$-likelihood function $(\log (\mathrm{L}))$, Akaike (AIC) and Schwarz's Bayesian (BIC) information criteria for models with heterogeneous residual variance (Het).

\begin{tabular}{cccccccccc}
\hline Model & $\mathbf{k}_{\mathbf{a}}$ & $\mathbf{k}_{\mathbf{m}}$ & $\mathbf{k}_{\mathbf{p}}$ & $\mathbf{k}_{\mathbf{c}}$ & $\mathbf{H e t}$. & $\mathbf{N P}$ & $\mathbf{L o g}(\mathbf{L})$ & $\mathbf{A I C}$ & $\mathbf{B I C}$ \\
\hline M3311 & 3 & 3 & 1 & 1 & 7 & 21 & $-57,484$ & 115,010 & 115,07 \\
M3322 & 3 & 3 & 2 & 2 & 7 & 25 & $-57,466$ & 114,982 & 115,06 \\
M3333 & 3 & 3 & 3 & 3 & 7 & 31 & $-57,439$ & 114,940 & 115,03 \\
M4253 & 4 & 2 & 5 & 3 & 7 & 41 & $-49,559$ & 99,201 & 99,328 \\
M4353 & 4 & 3 & 5 & 3 & 7 & 44 & $-39,036$ & 78,161 & 78,297 \\
M4363 & 4 & 3 & 6 & 3 & 7 & 50 & $-47,163$ & 94,427 & 94,582 \\
M4364 & $\mathbf{4}$ & $\mathbf{3}$ & $\mathbf{6}$ & $\mathbf{4}$ & $\mathbf{7}$ & $\underline{\mathbf{5 4}}$ & $\mathbf{- 3 6 , 2 4 0}$ & $\mathbf{7 2 . 5 8 8}$ & $\mathbf{7 2 . 7 5 5}$ \\
M4422 & 4 & 4 & 2 & 2 & 7 & 33 & $-49,877$ & 99,820 & 99,922 \\
M4433 & 4 & 4 & 3 & 3 & 7 & 39 & $-57,448$ & 114,974 & 115,09 \\
M4453 & 4 & 4 & 5 & 3 & 7 & 48 & $-41,714$ & 83,524 & 83,673 \\
M4454 & 4 & 4 & 5 & 4 & 7 & 52 & $-47,236$ & 94,576 & 94,737 \\
M4464 & 4 & 4 & 6 & 4 & 7 & 58 & $-38,018$ & 76,152 & 76,332 \\
M4465 & 4 & 4 & 6 & 5 & 7 & 63 & $-36,526$ & 73,179 & 73,374 \\
M4466 & 4 & 4 & 6 & 6 & 7 & 69 & $-38,345$ & 76,828 & 77,042 \\
M4533 & 4 & 5 & 3 & 3 & 7 & 44 & $-39,002$ & 78,092 & 78,228 \\
M4544 & 4 & 5 & 4 & 4 & 7 & 52 & $-41,649$ & 83,402 & 83,563 \\
M4555 & 4 & 5 & 5 & 5 & 7 & 62 & $-37,628$ & 75,380 & 75,572 \\
\hline
\end{tabular}


Several previous studies (MEYER, 2000; TORRES et al., 2000; ALBUQUERQUE; MEYER, 2001; EL FARO; ALBUQUERQUE, 2003) have indicated that heterogeneous residual variance structures provide superior fits to longitudinal cattle weight data, due to improved partition of total variance. By contrast, the assumption of homogeneous residual variance implies that environmental effects are the same at all ages, which is probably unrealistic. Moreover, a substantial portion of residual variance may contaminate the permanent animal environmental variance (HUISMAN et al., 2002).

In this study, the AIC and BIC identified model M4364, with heterogeneous residual variance structure, as the best fit (Table 3). However, as seen from examination of the eigenvalues (Table 4), as the order of each polynomial increased the proportion of variance explained by the additive direct genetic, maternal genetic, and animal and maternal permanent environmental effects decreased, in most cases to zero. The additive direct genetic variance alone was not completely explained (Table 4).

Table 4. Estimates of variances (diagonal), covariances (below the diagonal) and correlations (above the diagonal) between the random regression coefficients and their eigenvalues $(\lambda)$ in model M4364 for additive direct and maternal genetic effects and permanent animal and maternal environment, respectively.

\begin{tabular}{|c|c|c|c|c|c|c|c|c|}
\hline \multicolumn{9}{|c|}{ Model M4364 (Table 3) } \\
\hline & & 0 & 1 & 2 & 3 & 4 & 5 & $\lambda$ \\
\hline \multirow{4}{*}{$\begin{array}{l}\text { Additive Direct } \\
\text { Genetic }\end{array}$} & 0 & 637.67 & $\underline{0.88}$ & $\underline{-0.11}$ & $\underline{0.01}$ & & & 859.65 \\
\hline & 1 & 363.69 & $\overline{263.30}$ & $\overline{0.13}$ & $\overline{0.19}$ & & & 56.85 \\
\hline & 2 & -14.36 & 10.86 & $\overline{25.80}$ & $\underline{0.42}$ & & & 16.11 \\
\hline & 3 & 1.51 & 13.18 & 9.00 & $\overline{17.30}$ & & & 11.46 \\
\hline \multirow{3}{*}{ Maternal Genetic } & 0 & 20.13 & $\underline{0.85}$ & $\underline{0.02}$ & & & & 122.15 \\
\hline & 1 & 7.94 & 4.33 & $\underline{-0.51}$ & & & & 23.29 \\
\hline & 2 & 0.87 & -11.71 & $\overline{120.99}$ & & & & 0.0 \\
\hline \multirow{6}{*}{$\begin{array}{l}\text { Permanent Animal } \\
\text { Environment }\end{array}$} & 0 & 208.85 & $\underline{0.77}$ & $\underline{-0.26}$ & $\underline{-0.05}$ & $\underline{0.13}$ & $\underline{-0.01}$ & 340.28 \\
\hline & 1 & 135.60 & $\overline{147.64}$ & $\overline{-0.02}$ & $\overline{-0.56}$ & $\underline{-0.34}$ & $\overline{0.18}$ & 281.95 \\
\hline & 2 & -38.34 & -3.00 & 102.52 & $\underline{-0.38}$ & $\underline{-0.29}$ & $\underline{-0.32}$ & 130.31 \\
\hline & 3 & -2.48 & -23.58 & -13.52 & $\overline{11.95}$ & $\overline{0.21}$ & $\overline{0.17}$ & 31.74 \\
\hline & 4 & 15.09 & -33.00 & -23.98 & 6.03 & 63.74 & $\underline{-0.48}$ & 18.41 \\
\hline & 5 & -2.62 & 35.84 & -54.19 & 9.80 & -62.96 & $\overline{268.00}$ & 0.0 \\
\hline \multirow{4}{*}{$\begin{array}{c}\text { Permanent } \\
\text { Maternal } \\
\text { Environment }\end{array}$} & 0 & 143.30 & -0.002 & $\underline{-0.48}$ & -0.04 & & & 182.62 \\
\hline & 1 & -0.07 & $\overline{7.26}$ & $\underline{0.28}$ & -0.99 & & & 61.39 \\
\hline & 2 & -57.09 & 7.41 & $\overline{99.36}$ & -0.21 & & & 11.59 \\
\hline & 3 & -1.19 & -6.42 & -5.06 & $\overline{5.70}$ & & & 0.0 \\
\hline
\end{tabular}

The correlations between the intercept and the linear regression coefficients were high and positive for the additive direct genetic (0.88), maternal (0.85), and permanent animal environmental (0.77) effects. For the permanent maternal environmental effect, correlation between the intercept and the linear regression coefficient was low and negative (-0.002). Utilizing weights from birth to 630 days of age in Nelore cattle, Albuquerque and Meyer (2001) reported high and positive correlations between the intercept and the linear regression coefficients for all random effects. Similarly, Dias et al. (2006) also estimated high and positive correlations between the intercept and the linear regression coefficients for all random effects, utilizing weight records from birth to 550 days of age in Tabapuã cattle.

Therefore, model M4364 accounted well for variances, with a reduced number of random effects, 
leading to improved data structure and consequently facilitating convergence. The estimates of additive direct and maternal genetic effects, and permanent animal and maternal environmental effects increased with age of the animals, suggesting a positive response to election during this period (Figure 3). Albuquerque and Meyer (2001), Nobre et al. (2003), and Dias et al. (2006) also observed that variances increased with age. Based upon the present results one may conclude that weights obtained from birth to 550 days of age possess high additive direct genetic and phenotypic variance, enabling good responses to selection, in agreement with Albuquerque and Meyer (2001); Cyrillo (2003); Nobre et al. (2003); Boligon et al. (2010) and Sousa Júnior et al. (2010).

Figure 3. Trends in estimates of additive direct genetic variance maternal genetic variance, permanent animal environment, and permanent maternal environment for a model with heterogeneous residual variance (M4364).

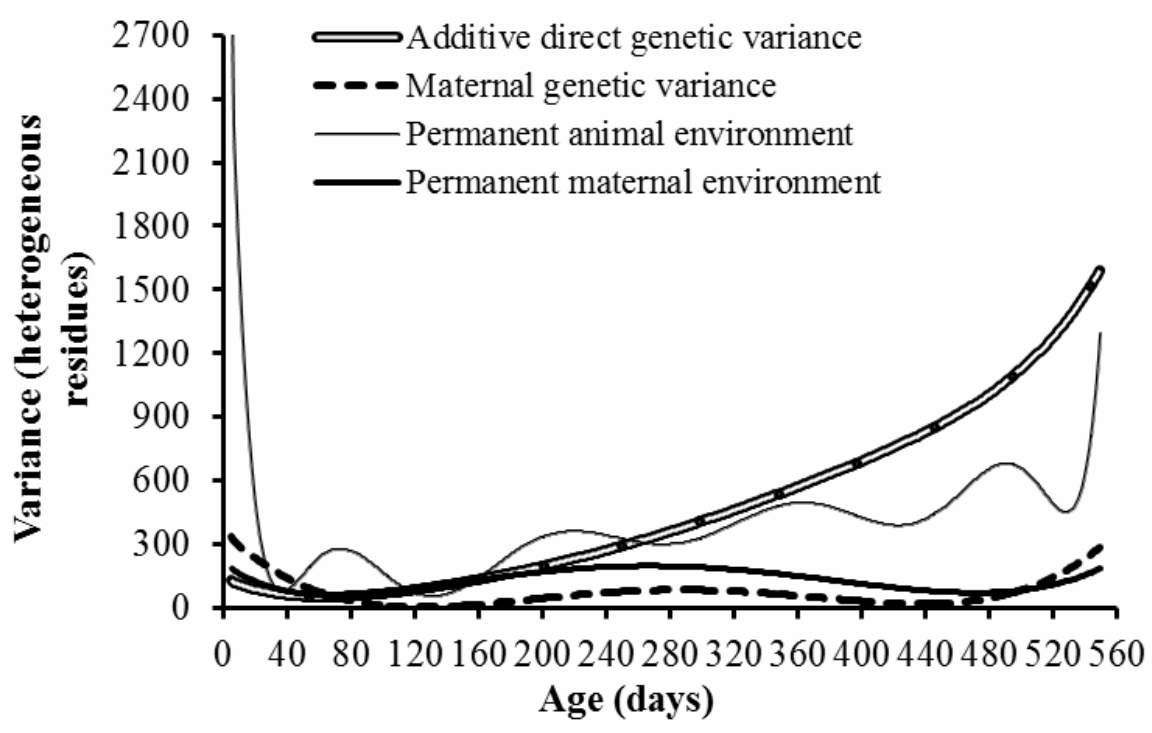

Additional support for the use of a model with heterogeneous residual variance is given by the fact that maternal genetic, and permanent animal and maternal environmental variances increased progressively with age of the animals. The partition of residual variance improved the model fit and the accuracy of the estimates of variance components, as well as preventing the contamination of the permanent animal environmental variance.
The estimates of direct genetic correlations between ages were high and positive, indicating that selection at younger ages can be effective, with improvements in one trait leading to improvements in other traits (Table 5). Similar values for genetic correlations were reported by Boligon et al. (2008), Albuquerque and El Faro et al. (2008), and Souza et al. (2010). 
Table 5. Estimates of correlations for model 4364 with heterogeneous residual variance.

\begin{tabular}{ccccc}
\hline Age (days) & 210 & 365 & 450 & 550 \\
\hline 120 & $\mathbf{0 . 9 3}$ & 0.78 & 0.73 & 0.62 \\
210 & & $\mathbf{0 . 9 4}$ & 0.89 & 0.74 \\
365 & & $\mathbf{0 . 9 7}$ & 0.81 \\
450 & & & & $\mathbf{0 . 9 1}$ \\
\hline
\end{tabular}

The estimates of direct, maternal, and total heritabilities along the growth curve differed according to the residual variance structure adopted (Figure 4). Thus, heritabilities estimated using a heterogeneous residual variance model were superior to those obtained using a homogeneous residual variance model. Similar results have been reported previously (SILVA, 2004; BOLIGON, 2008).

Figure 4. Trends in estimates of direct, maternal and total heritabilities, using models with homogeneous (M4465, Table 2) or heterogeneous (M4364, Table 3) residual variance.

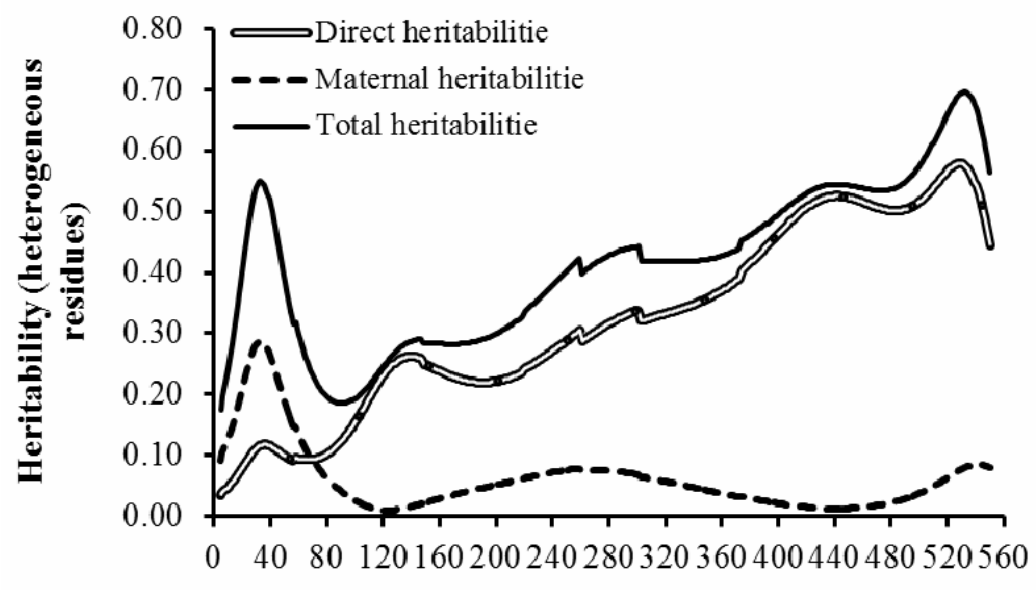

Age (days)

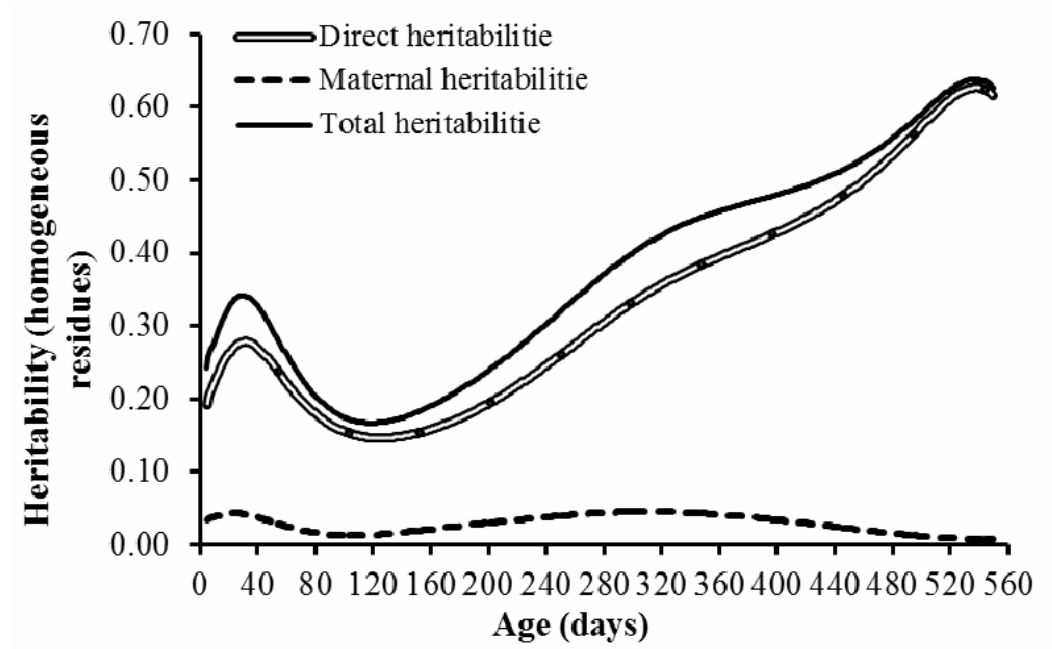


The direct heritability values obtained in the study suggest the presence of sufficient genetic variability to enable rapid genetic progress in response to selection, from weaning (at 210 days of age) onward, as these values remained high thereafter. Similar results were reported by Palharim et al. (2013). Therefore, we recommend that selection be conducted at younger ages in order to permit selection of earlier-maturing animals and to maximize profits.

The low maternal heritability observed indicates the small contribution of the maternal effect along the entire growth curve of the animal, as well as the weak selection applied for this trait in herd within the humid tropical region of Brazil. These results are in agreement with those of Albuquerque and Meyer (2001); Nobre et al. (2003); Silva (2004); and Dias et al. (2006). Considering these results and those shown in Figure 4, it is clear that within the humid tropical region of Brazil weight is a dominant selection criterion, which might increase costs of production through an indirect increase in mature size of the herd.

\section{Conclusions}

Random regression models with heterogeneous variance structures provide best fits to longitudinal growth data, as well as more accurate and precise estimates of (co)variance components. There is sufficient additive genetic variance in body weight to allow satisfactory responses to selection, even at younger ages, e.g., at weaning. On the other hand, other economically-important traits such as reproductive capacity and carcass quality are not expressed in Nelore cattle until after 12 months of age.

\section{Acknowledgements}

The authors are grateful to the National Association of Breeders and Researchers (Associação Nacional de Criadores e Pesquisadores - ANCP) by disposing datasets for this study.

\section{References}

AKAIKE, H. Anew look at statistical model identification. IEEE Trans. on Automatic Control, Notre Dame, v. 19, n. 6, p. 716-723, 1974.

ALBUQUERQUE, L. G.; EL FARO, L. Comparação entre os valores genéticos para características de crescimento de bovinos da raça Nelore preditos com modelos de dimensão finita e infinita. Revista Brasileira de Zootecnia, Viçosa, MG, v. 37, n. 2, p. 238-246, 2008.

ALBUQUERQUE, L. G.; MEYER, K. Estimates of covariance functions for growth of Nelore cattle applying a parametric structure to model within animal correlations. Livestock Production Science, Amsterdam, v. 93, n. 3, p. 213-222, 2005.

. Estimates of direct and maternal genetic effects for weights from birth to 600 days of age in Nelore cattle. Journal of Animal Breeding and Genetics, v. 118, n. 2, p. 83-92, 2001.

BIASSUS, I. O.; COBUCI, J. A.; COSTA, C. N.; RORATO, P. R. N.; BRACCINI NETO, J.; CARDOSO, L. L. Genetic parameters for production traits in primiparous Holstein cows estimated by random regression models. Revista Brasileira de Zootecnia, Viçosa, MG, v. 40, n. 1, p. 85-94, 2011.

BOLIGON, A. A. Estimativas de (co)variância genética de pesos do nascimento até a maturidade em rebanhos da raça Nelore usando modelos de regressão aleatória e de características múltiplas. 2008. Dissertação (Mestrado em Genética e Melhoramento Animal) - Universidade Estadual Paulista, Jaboticabal.

BOLIGON, A. A.; SILVA, J. A. V.; SESANA, R. C.; SESANA, J. C.; JUNQUEIRA, J. B.; ALBUQUERQUE, L. G. Estimation of genetic parameters for body weights, scrotal circumference, and testicular volume measured at different ages in Nellore cattle. Journal of Animal Science, Champaign, v. 88, n. 4, p. 1215-1219, 2010.

BRASIL. Brasil projeções do agronegócio brasileiro 2010/ 2011 a 2020/2021. Ministério da Agricultura, Pecuária e Abastecimento, Assessoria de Gestão Estratégica. Brasília, DF, 2011. 59 p. Disponível em: <http://www.agricultura.gov.br/arq_editor/file/ Ministerio/gestao/projecao/PROJECOES\%20DO $\% 20$ AGRONEGOCIO \%202010-11\%20a\%202020-21\%20 -\%202_0.pdf>. Acesso em: 01 mar. 2014.

CYRILlo, J. N. S. G. Estimativas de funções de covariância para o crescimento de machos Nelore utilizando modelos de regressão aleatória. 2003. Tese (Doutorado em Produção Animal) - Universidade Estadual Paulista, Jaboticabal. 
DIAS, L. T.; ALBUQUERQUE, L. G.; TONHATI, H.; TEIXEIRA, R. A. Estimação de parâmetros genéticos para peso do nascimento aos 550 dias de idade para animais da raça Tabapuã utilizando-se modelos de regressão aleatória. Revista Brasileira de Zootecnia, Viçosa, MG, v. 35, n. 5, p. 1915-1925, 2006.

EL FARO, L.; ALBUQUERQUE, L. G. Utilização de modelos de regressão aleatória para produção de leite no dia de controle, com diferentes estruturas de variâncias residuais. Revista Brasileira de Zootecnia, Viçosa, MG, v. 32, n. 5, p. 1104-1113, 2003.

FERRAZ, J. B. S.; ELER, J. P. Parceria público x privada no desenvolvimento de pesquisa em melhoramento genético animal. Revista Brasileira de Zootecnia, Viçosa, MG, v. 39, p. 216-222, 2010. Suplemento Especial.

HUISMAN, A. E.; VEERKAMP, R. F.; VAN ARENDONK, J. A. M. Genetic parameters for various random regression models to describe the weight data of pigs. Journal of Animal Science, Champaign, v. 80, n. 3, p. $575-582,2002$.

LIRA, T. S.; PEREIRA, L. S.; LOPES, F. B.; FERREIRA, J. L.; LÔBO, R. B.; SANTOS, G. C. J. Tendências genéticas para características de crescimento em rebanhos Nelore criados na região do Trópico Úmido do Brasil. Ciência Animal Brasileira, Goiânia, v. 14, n. 1, p. 23-31, jan./mar. 2013.

MEYER, K. Random regression to model phenotypic variation in monthly weights of Australian beef cows. Livestock Production Science, Amsterdam, v. 65, n. 1-2, p. 19-38, 2000.

MEYER, K.; WOMBAT. A tool for mixed model analyses in quantitative genetics by restricted maximum likelihood (REML). Journal of Zhejiang University Science, v. 8, n. 11, p. 815-821, 2007.

NEPOMUCENO, L. L.; ANDRADE, R. J.; LOPES, F. B.; LIRA, T. S.; VIEIRA, L. F.; SANTOS, G. C. J.; PEREIRA, L. S.; FERREIRA, J. L. Associações genéticas entre o perímetro escrotal e as características produtivas e reprodutivas em rebanho Nelore criado na região norte do Tocantins. Revista Acadêmica, Ciências Agrárias e Ambientais, Curitiba, v. 10, n. 3, p. 253-261, jul./set. 2012.

NOBRE, P. R. C.; MISZTAL, I.; TSURUTA, S.; BERTRAND, J. K. L.; SILVA L. O. C.; LOPES, P. S. Analyses of growth curves of Nelore cattle by multipletrait and random regression models. Journal of Animal Science, Champaign, v. 81, n. 4, p. 918-926, 2003.

NUNEZ-ANTÓN, V. N.; ZIMMERMAN, D. L. Modelling nonstationary longitudinal data. Biometrics, Arlington, v. 56, n. 3, p. 699-705, 2000.
PALHARIM, D. A.; ARAÚJO, C. V.; BITTENCOUR, T. C. B. S. C.; ARAÚJO, S. I.; LÔBO, R. B.; BEZERRA, L. A. F. Estimativas de herdabilidade para o desempenho ponderal na raça Nelore no Mato Grosso. Scientific Electronic Archives, Sinop, v. 3, n. 1, p. 59-62, 2013.

SANTOS, G. C. J.; LIRA, T. S.; PEREIRA L. S.; LOPES, F. B.; FERREIRA, J. L. Efeitos não genéticos sobre características produtivas em rebanhos Nelore criados na região norte do Brasil. Acta Veterinária Brasilica, Mossoró, v. 5, n. 4, p. 385-392, 2011.

SANTOS, G. C. J.; LOPES, F. B.; MARQUES, E. G.; SILVA, M. C.; CAVALCANTE, T. V.; FERREIRA, J. L. Tendência genética para pesos padronizados aos 205, 365 e 550 dias de idade de bovinos Nelore da região norte do Brasil. Acta Scientiarum. Animal Sciences, Maringá, v. 34, n. 1, p. 97-101, jan./mar. 2012.

SCHWARZ, G. Estimating the dimension of the model. The Annual of Statistics, v. 458, n. 6, p. 127-132, 1998.

SILVA, I. S. Componentes de (co)variância e parâmetros genéticos para características de crescimento de bovinos da raça Guzerá usando diferentes estratégias de análise. 2004. Tese (Doutorado em Ciência Animal e Pastagens) - Escola Superior de Agricultura Luiz Queiroz da Universidade de São Paulo, Piracicaba, São Paulo.

SOUSA JÚNIOR, S. C.; OLIVEIRA, S. M. P.; ALBUQUERQUE, L. G.; BOLIGON, A. A.; MARTINS FILHO, R. Estimação de funções de covariância para características de crescimento da raça Tabapuã utilizando modelos de regressão aleatória. Revista Brasileira de Zootecnia, Viçosa, MG, v. 39, n. 5, p. 1037-1045, 2010.

SOUZA, J. C.; SILVA, L. O. C.; SIMÕES, G. H.; MOSER, J. T.; OSTAPECHEN, J.; PINTO, P. H. N.; RUVIERO, V.; MALHADO, C. H. M.; FERRAZ FILHO, P. B.; FREITAS, J. A.; SERENO, J. R. B. Tendências ambientais e genéticas para características produtivas de bovinos da raça Nelore. Archivos Latinoamericanos de Producción Animal, v. 16, n. 2, p. 85-90, 2008.

TORRES, R. A.; BERGMANN, J. A. G.; COSTA, C. N.; PEREIRA, C. S.; VALENTE, J.; PENNA, V. M.; TORRES FILHO, R.A.;ARAÚJO, C. V. Heterogeneidade de variância e avaliação genética de bovinos da raça Holandesa no Brasil. Revista Brasileira de Zootecnia, Viçosa, MG, v. 29, n. 4, p. 1050-1059, 2000.

WOLFINGER, R. Covariance structure selection in general mixed models. Communications in Statistics, Ontario, v. 22, n. 4, p. 1079-1106, 1993. 
